\title{
海馬における興奮性神経伝達調節機構の多角的解析と糖鎖機能分析ツールの開発
}

\author{
南彰

\section{Multidimensional Analysis of Hippocampal Excitatory Neurotransmission and Development of Analytical Tools for Glycans}

\author{
Akira Minami \\ Department of Biochemistry, School of Pharmaceutical Sciences, University of Shizuoka; \\ 52-1 Yada, Suruga-ku, Shizuoka 422-8526, Japan.
}

(Received July 15, 2015)

\begin{abstract}
Sialidase removes sialic acid residues from sialoglycoconjugates such as glycoproteins and glycolipids. Since sialic acid plays crucial roles in synaptic plasticity and memory in the hippocampus, the regulation of sialyl signaling by sialidase is also necessary for neural functions. However, since mammalian sialidase activity is remarkably weak, it has been difficult to detect sialidase activity in mammalian tissues. Determination of the distribution of sialidase activity in living mammalian tissues would provide much valuable information for understanding the roles of sialidase in physiological functions. Therefore, we synthesized a novel benzothiazolylphenol-based sialic acid derivative (BTP-Neu5Ac) as a fluorescent sialidase substrate. After cleavage of BTP-Neu5Ac, which is water soluble and shows little fluorescence, with sialidase, the water-insoluble fluorophore benzothiazolylphenol (BTP) released from BTP-Neu5Ac stains tissue and shows bright fluorescence. BTP-Neu5Ac can visualize sialidase activity in brain tissue with high levels of sensitivity and specificity. The sialidase expression level is markedly high in various human cancers such as colon, renal, prostate, and ovarian cancers. BTP-Neu5Ac can detect human colon cancers sensitively. Thus, BTP-Neu5Ac is useful not only for physiological research but also as a cancer probe. BTP-Neu5Ac is now being used in virology research. In this review, methods for histochemical imaging of sialidase activity and the role of sialidase in hippocampal memory are described based on the author's study of multidimensional analysis of hippocampal excitatory neurotransmission and development of analytical tools for glycans, which was awarded a prize by the Tokai branch of the Pharmaceutical Society of Japan.
\end{abstract}

Key words__ sialidase; histochemical imaging probe; hippocampus; memory; BTP3-Neu5Ac; BTP4-Neu5Ac

\section{1. はじめに}

神経における糖鎖の機能は不明な点が多い.その 一因として糖鎖の機能を解析するためのツールが限 られていることが挙げられる。特に神経伝達や記憶 形成などの短時間で変化する現象において糖鎖シグ ナルを理解するためには，新たな糖鎖機能の解析 ツールが必要である。こういつた背景から，筆者ら の研究グループでは糖鎖修飾関連酵素の酵素活性を 可視化するプローブの開発を行っている. ${ }^{1-3)}$ 中で もシアリダーゼの酵素活性を高感度に検出するプ ローブ benzothiazolylphenol-based sialic acid deriva-

静岡県立大学大学院薬学研究院生化学講座 (T422-8526 静岡市駿河区谷田 52-1)

e-mail: aminami@u-shizuoka-ken.ac.jp

本総説は, 平成 26 年度日本薬学会東海支部学術奨励賞

の受賞を記念して記述したものである. tive (BTP-Neu5Ac) は，神経の研究領域のみなら ず，がんの検出1)やウイルスの検出 ${ }^{4-7)}$ といつた研究 領域にも利用範囲を広げている。本総説では，平成 26 年度日本薬学会東海支部学術奨励賞の受賞内容 「海馬における興奮性神経伝達調節機構の多角的解 析と糖鎖機能分析ツールの開発」のうち，シアリ ダーゼの高感度な酵素活性イメージング法の開発と 記憶における役割について焦点を絞り概説する.

2. シアリダーゼについて

シアル酸は主に糖鎖の未端を修飾する酸性糖であ

り, 細胞表面に負電荷を提供する. シアリダーゼ は，このシアル酸を糖鎖から遊離させる加水分解酵 素であり，記憶やシナプス可塑性，軸索伸長，神経 分化など多くの神経機能において重要な役割を担 う. ${ }^{8-11)}$ 動物のシアリダーゼには NEU1, NEU2, NEU3， NEU4 の 4 種類のアイソザイムがあり，ど 
Table 1. Substrates for Sialidase Activity Measurement

\begin{tabular}{lcccc}
\hline \hline & \multicolumn{4}{c}{ Artificial sialidase substrate } \\
\cline { 2 - 5 } & 4MU-Neu5Ac & X-Neu5Ac & X-Neu5Ac+FRV LB & BTP-Neu5Ac \\
\hline Staining & Impossible & Possible & Possible & Possible \\
\hline Sensitivity & High & Low & High & High \\
\hline Specificity & High & High & $\begin{array}{c}\text { Low } \\
\text { (2 step reaction) }\end{array}$ & $\begin{array}{c}\text { High } \\
\text { (1 step reaction) }\end{array}$ \\
\hline
\end{tabular}

のアイソザイムも脳に発現している. ${ }^{12)}$ NEU1 から NEU4 はそれぞれ細胞内における主な局在部位が異 なり, NEU1 はリソソーム, NEU2 は細胞質, NEU3 は形質膜に存在する。またヒトの NEU4 に は，ミトコンドリア移行シグナルを持つもの （NEU4L）と持たないもの（NEU4S）の 2 つのア イソザイムがあり, NEU4 はミトコンドリアや小胞 体に局在するという報告やリソソームに局在すると いう報告がある，上記に示した主な局在部位のほか にも, どのアイソザイムも細胞表面又は細胞外液中 に存在していることを示す報告がある. ${ }^{13-15)}$ また, 各シアリダーゼアイソザイムは基質特異性が異なる. NEU1 はオリゴ糖や糖タンパク質, NEU2 はガング リオシドや糖タンパク質, NEU3 はガングリオシド, NEU4 はオリゴ糖や糖タンパク質, ガングリオシ ド，シアル酸重合体（polysialic acids; PSA）をそ れぞれ効率よく加水分解する. ${ }^{16-20)}$

動物に発現するシアリダーゼの酵素活性は, ウイ ルスやバクテリアなどのシアリダーゼと比較して著 しく低く, 動物組織におけるシアリダーゼ活性の分 布を知ることは極めて困難であった。 そこで筆者ら は神経機能におけるシアリダーゼの機能解析を目的 として, 組織で利用可能な高感度シアリダーゼ活性 イメージング法の開発を行った。

\section{3. シアリダーゼ活性プローブ}

シアリダーゼ活性の測定に頻繁に利用される人工 基質として， 4-methylumbelliferyl- $\alpha$-D- $N$-acetylneuraminic acid (4MU-Neu5Ac) がある. 無蛍光で ある 4MU-Neu5Ac がシアリダーゼによって加水分 解を受けると 4-methylumbelliferone (4MU) が遊 離され，蛍光を発するようになる。この蛍光強度を 測定することにより， シアリダーゼの活性強度を定 量することができる。しかし，4MU は水溶性が高 く, 組織の染色などに利用することはできない
(Table 1).

シアリダーゼ活性の組織染色には, 人工基質である 5-bromo-4-chloroindol-3-yl- $\alpha$-D- $N$-acetylneuraminic acid (X-Neu5Ac) が利用されてきた。 X-Neu5Acは シアリダーゼによる加水分解後, $\mathrm{X}$ が酸化されて 水に難溶性の藍色となり, この色素が組織に沈着す

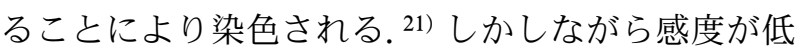
く, 哺乳動物のシアリダーゼ活性の分布を知ること は困難であった（Table 1)。X-Neu5Ac の感度を高 めるために，アゾ色素である Fast Red Violet LB （FRV LB）が利用される。 ${ }^{22,23)}$ FRV LB はシアリ ダーゼによって遊離した X と反応し, 赤色蛍光色 素 (ex/em: $550 \mathrm{~nm} / 696 \mathrm{~nm})$ となる [Fig. 1(A)]. この方法を組織染色に利用し, ラットの脳切片を染 色したところ，脳梁（corpus callosum）や背側海 馬交連 (dorsal hippocampus commissure), 海馬白 板 (alveus) や海馬采 (fimbria), 内包（internal capsule), 大脳脚 (cerebral peduncle) などの白質 領域が強く染色された [Fig. 2(A)]. 22) しかしなが ら，X-Neu5Ac と FRV LBを利用した染色では反 応に 2 段階を要することから, 染色の特異性に疑問 が残る [Fig. 1(A)].

そこで, 筆者らは 1 段階の反応でシアリダーゼ活 性を可視化することのできる蛍光プローブ BTPNeu5Ac を合成した $[$ Fig. 1 (B) ] . 無蛍光の水溶性

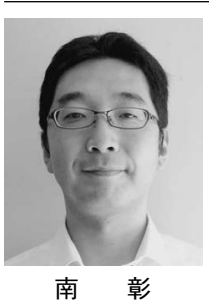

2005 年 3 月, 静岡県立大学大学院薬学 研究科博士後期課程修了 (博士 (薬学) ), 2004-2006 年度日本学術振興会特別研 究員, 2005 年 4 月静岡県立大学客員研 究員, 同年 6 月米国カリフォルニア大 学バークレー校博士研究員, 2008 年 1 月静岡県立大学薬学部・助教 (現職). 2011 年日本生化学会中部支部奨励賞, 2014 年日本薬学会東海支部奨励賞受賞 など. 
A

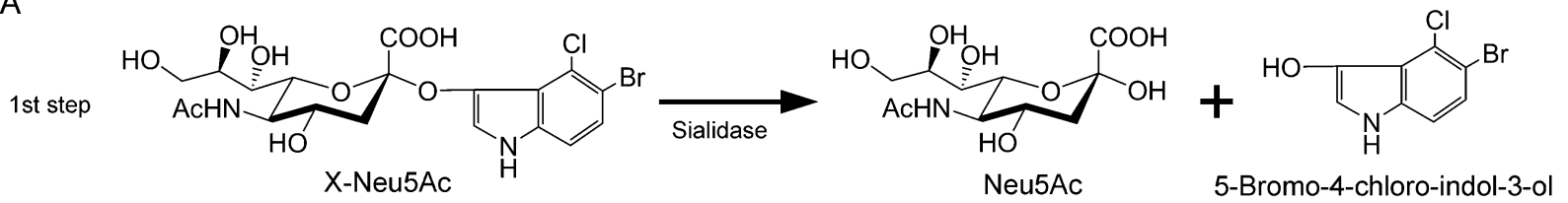

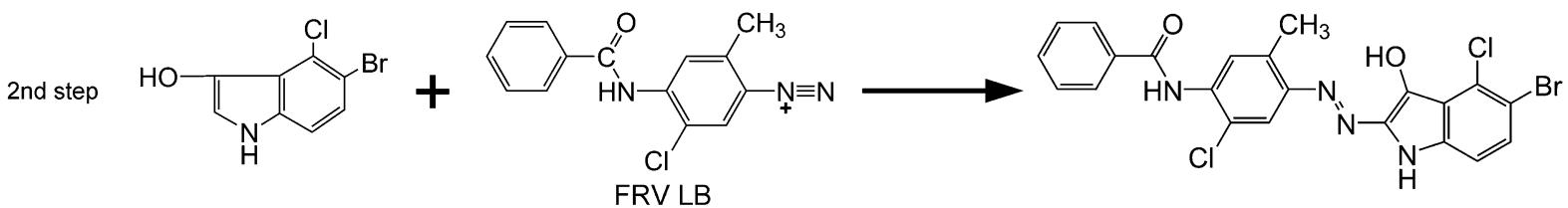

Fluorescent compound (ex/em: $550 \mathrm{~nm} / 696 \mathrm{~nm}$ )

B

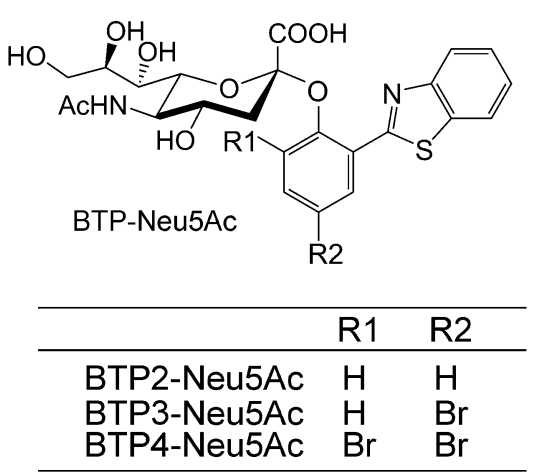<smiles>CC(C)(C)[N+](C)(C)C</smiles><smiles>[R2]c1cc([R1])c(O)c(-c2nc3ccccc3s2)c1</smiles>

BTP (fluorescent compound)

Fig. 1. Chemical Reactions for Sialidase Activity Measurement Fluorescence is produced by reaction with sialidase and X-Neu5Ac/FRV LB (A) or BTP-Neu5Ac (B).
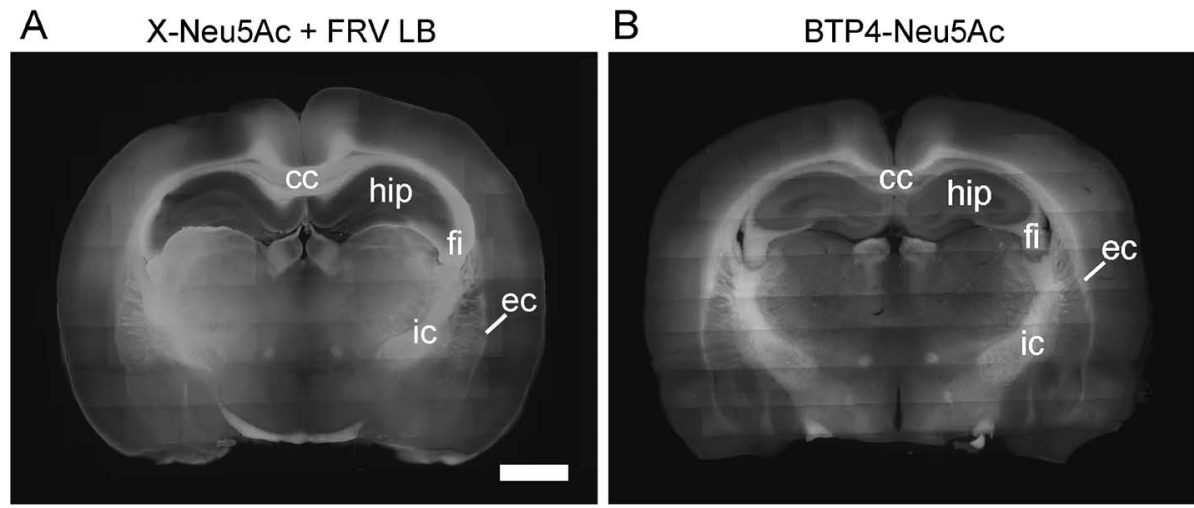

Fig. 2. Imaging of Sialidase Activity in the Rat Brain with X-Neu5Ac/FRV LB or BTP4-Neu5Ac ${ }^{1,22)}$

Acute coronal brain slices were stained with X-Neu5Ac/FRV LB (A) or BTP4-Neu5Ac (B) at pH 7.3. Brighter fields show higher sialidase activity. Abbreviations: cc, corpus callosum; fi, fimbria; ic, internal capsule; ec, external capsule; hip, hippocampus. Scale bar, $2 \mathrm{~mm}$.

物質ある BTP-Neu5Ac はシアリダーゼによる加水 分解を受けると，液晶ディスプレイ素材などで使わ れる蛍光物質 benzothiazolylphenol (BTP) が遊離 される (Fig. 3)。このBTP は水溶性が低いため細 胞膜に沈着し，組織を染色することができる．３種 類の BTP 誘導体（BTP2, BTP3, BTP4）にシアル 酸を結合させた BTP2-Neu5Ac やBTP3-Neu5Ac,
BTP4-Neu5Ac についてラットの脳急性切片を染色 したところ，どの基質も染色に利用することができ た. ${ }^{1)}$ Figure 2(B) に BTP4-Neu5Ac によるラット脳 の染色像を示す。X-Neu5Ac と FRV LB を組み合 わせて染色した蛍光の分布と同様に, BTP4Neu5Ac の染色像においても脳の白質領域で強い蛍 光が観察された. BTP4-Neu5Ac による蛍光はシア 


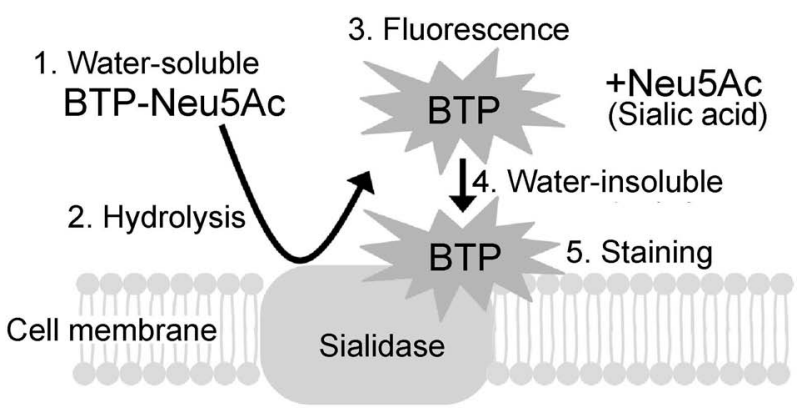

Fig. 3. Staining Mechanism of BTP-Neu5Ac

1: BTP-Neu5Ac is water-soluble and shows little fluorescence. 2: BTPNeu5Ac can be hydrolyzed with sialidase. 3: BTP shows intense fluorescence. 4: BTP is a water-insoluble fluorophore. 5: Tissue is stained with BTP.

リダーゼの阻害剤（2,3-dehydro-2-deoxy- $N$-acetylneuraminic acid; DANA）によって著しく減弱する ことから, BTP4-Neu5Ac はシアリダーゼの酵素活 性を特異的に検出できることが確かめられてい る. 1)

\section{4. 大腸がんの検出}

大腸がんや卵巣がん，前立腺がん，腎細胞がんな どの様々ながんでは，シアリダーゼが異常に高い酵

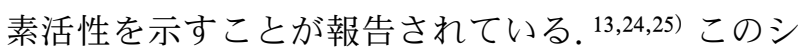
アリダーゼの酵素活性を高感度にイメージングする ことができれば，がんの早期発見や手術時に取り残 しなくがんを摘出することが可能になる。 そこで, 内視鏡による観察時にがん部位を高感度に可視化す ることのできる技術開発を目的として，マウス大腸 がん細胞の同所移植モデルを作製し BTP4-Neu5Ac で染色した。その結果，がん部位が明瞭に染色され ることを見い出した. ${ }^{1)}$ ヒト大腸がん組織（ステー ジ T3 と T4）についても BTP4-Neu5Acで染色した ところ, 強い蛍光が観察された (Fig. 4)。ヘマト キシリンーエオシンによる形態観察によって, 蛍光 を発する部位にがんがあることを確認している.

BTP-Neu5Ac はがんの検出に利用できる可能性が あり, 診断や治療への応用が期待される.

\section{5. 海馬におけるシアリダーゼの役割}

われわれはこれまでに，記憶の場である海馬にお いてシアリダーゼ活性の分布を検討した。海馬の主 要なグルタミン酸作動性神経の 1 つに，歯状回顆粒 細胞から CA3 錐体細胞に投射する苔状線維がある. ラット海馬をX-Neu5Ac/FRV LB を利用して染色 した観察像から，苔状線維終末に比較的強いシアリ ダーゼ活性があることを見い出している. 22)これは,
BTP3-Neu5Ac を利用して染色した場合にも再現さ れる(投稿中).

苔状線維終末におけるシアリダーゼは，軸索伸長 やシナプス形成に関与することが示唆されている. 成体脳の海馬において，苔状線維の起始細胞である 歯状回顆粒細胞のうち新生したばかりの未熟な顆粒 細胞は，神経細胞接着分子 (neural cell adhesion molecule； NCAM）にPSA が結合している．新生 顆粒細胞から伸長した軸索は新生後およそ 10-11 日 にCA3 領域に達する. ${ }^{26)}$ 新生 3-4 週間後には新生 ニューロンの NCAM 上に発現する PSA が消失し, 12 週間後では観察されなくなる. ${ }^{27,28)}$ PSA を酵素 であらかじめ除去すると，このマウスの苔状線維で は異所性の投射や終末形成が観察される. ${ }^{8)}$ また, ラット海馬由来の初代培養神経細胞において，シア リダーゼ活性を抑制すると軸索の形成や伸長が抑制 される. ${ }^{29,30)} こ れ ら の$ 知見から, 苔状線維の正常な 軸索伸長にはシアリダーゼが必要であると考えられ る.

また，苔状線維終末のシアル酸は，シナプス形成 を調節する。成熟した苔状線維終末では PSA の発 現が観察されないのに対し，シナプス小胞やミトコ ンドリアの数が少なく未熟な苔状線維終末では PSA の発現が観察される. 苔状線維のシナプス前 終末は大きいもので $10 \mu \mathrm{m}$ もある巨大シナプスを 形成するが，それに対応するシナプス後スパインも また巨大な棘状瘤を形成する．PSA を発現する苔 状線維終末では，この棘状瘤の形成過程で起こる $\mathrm{CA} 3$ 錐体細胞樹状突起からの陥入が観察される. ${ }^{31)}$ これらの形態観察の結果から，適切なタイミングと 場所でシアル酸が除去されることによって，苔状線 維終末のシナプスが成熟すると考えられる.

また，シアリダーゼは海馬神経の活動レベルの制 御に係わる。シアリダーゼ阻害薬 DANA を作用さ せると，海馬の自発的な同期活動 32 やて九かん発作

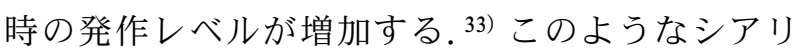
ダーゼによる神経興奮の抑制には，電位依存性ナト リウムチャネルを修飾する糖鎖構造からのシアル酸 脱離が関与するようである. ${ }^{34)}$ また，PSA による糖 鎖修飾によって，N-methyl-D-aspartate (NMDA) 型グルタミン酸受容体や $\alpha$-amino-3-hydroxyl-5methyl-4-isoxazolepropionate (AMPA) 型グルタミ ン酸受容体の活性が変化する. ${ }^{35,36)}$ さらに, PSA に 
A

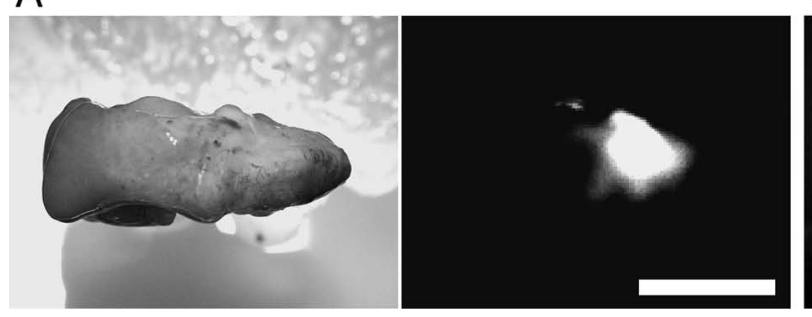

B

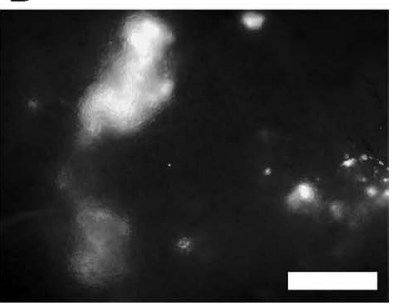

Fig. 4. Detection of Human Colon Cancer with BTP4-Neu5Ac1)

A, A human colon cancer tissue was stained with BTP4-Neu5Ac. Left and right panels show photographic and fluorescent images, respectively. Scale bar, 10 $\mathrm{mm}$. B, Enlarged fluorescence images of colon cancer tissue were acquired by using a fluorescent microscope. Scale bar, $500 \mu \mathrm{m}$.

脳由来神経栄養因子（brain-derived neurotrophic factor； BDNF）やドパミンなどが結合することも 報告されている. ${ }^{37,38)}$ これらの知見から，海馬の神 経活動はシアリダーゼによるシアル酸シグナルの調 節を介して多角的に制御されていると考えられる.

6. 記憶におけるシアリダーゼの役割

糖タンパク質や糖脂質に結合したシアル酸は記憶 において重要な役割を担う. 39$)$ モリス水迷路や Y 字 迷路で評価した記憶能や海馬のシャッファー側枝一 CA1 錐体細胞間におけるシナプス可塑性は, ガン グリオシド GQ1bに含まれるシアル酸によって増

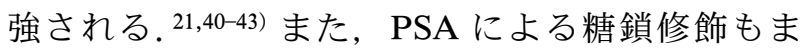
た，正常な記憶やシナプス可塑性を発揮する上で不 可欠である. ${ }^{9,10,44-46)}$ 海馬に外因性のシアリダーゼ を投与すると海馬依存性記憶やシナプス可塑性が影 響を受けることから，シアリダーゼによるシアル酸 シグナルの制御もまた記憶に関与すると考えられ る. 9,10,44-46) 筆者らは, ラット海馬に DANA を添加 して内在性のシアリダーゼを阻害すると, 海馬依存 性の記憶能が低下することを見い出している（投稿 中).

動物が持つシアル酸の主な分子種として $N$-アセ チルノイラミン酸 (Neu5Ac) とN-グリコリルノイ ラミン酸（N-glycolylneuraminic acid; Neu5Gc）が 知られている. Neu5Ac は哺乳動物の脳に豊富に存 在し, 記憶や神経回路形成, 神経伝達の調節に重要 な役割を担う。一方 Neu5Gc は，脳において Neu5Gcの合成に係わる酵素 (CMP-Neu5Ac hydroxylase；CMAH）が発現していないことから，脳に含 まれる量は極めて微量である。また，ヒトは CMAH を欠損しており, Neu5Gc を合成すること ができない。筆者らは，ラジオアイソトープ標識さ れた Neu5Gc を尾静脈に投与したところ, 投与 3 時
間後に海馬から比較的高い放射活性が検出された (Fig. 5). ${ }^{47)}$ 海馬に含まれる放射活性を詳細に解析 したところ，GM1 や GD1a, GD1b, GT1b, GQ1bな どのガングリオシドから放射活性が検出された. シ アリダーゼは Neu5Ac と比較して Neu5Gc に対する 基質特異性が低い. ${ }^{48-50)}$ 食慨などに由来して血中に 取り込まれた Neu5Gc のうち一部は脳に移行し, シ アリダーゼによる Neu5Ac の加水分解を競合阻害す ることによってシアリダーゼによるシアル酸シグナ ルの制御が乱れ，海馬の機能に影響する可能性があ る.

\section{7. おわりに}

シアリダーゼは外界からの刺激によって細胞内局 在や細胞外の酵素活性を変化させることが報告され ている. ${ }^{15,51-53)}$ 海馬から得た細胞膜画分に含まれる シアリダーゼ活性はてんかん発作後に増加すること から, ${ }^{51)}$ 神経興奮に伴って細胞表面上のシアリダー ゼ活性が変化している可能性がある. シアル酸脱離 による細胞表面電荷のダイナミックな変化は, シア ル酸シグナリングが関与するシナプス可塑性や記 憶, 神経伝達, 神経接着, AMPA 受容体輸送など に影響を与えることが予想される。神経機能におけ るシアリダーゼの役割を理解するためには, 神経活 動と連動したシアリダーゼ活性の変化を明らかにす る必要がある。

また，BTP を活用した酵素活性イメージングプ ローブはシアリダーゼ以外の様々な酵素にも拡充し ている. ${ }^{2,3}$ BTP の蛍光発色団は分子サイズが小さ いことから， BTP を含有する基質は酵素の活性中 心へのアクセスが比較的容易であると考えられる. 今後, これらの糖鎖機能分析ツールを生理機能の解 析や疾患の診断や治療などに活用し, 糖鎖研究の発 展と医療技術の提供に寄与できれば幸甚である. 
A
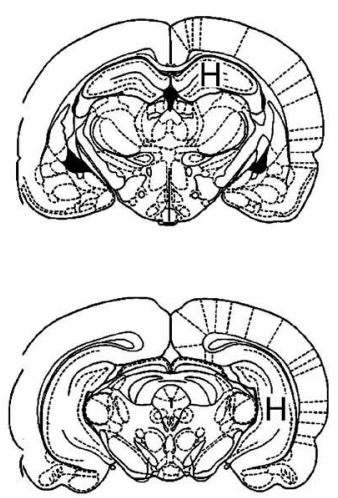

B
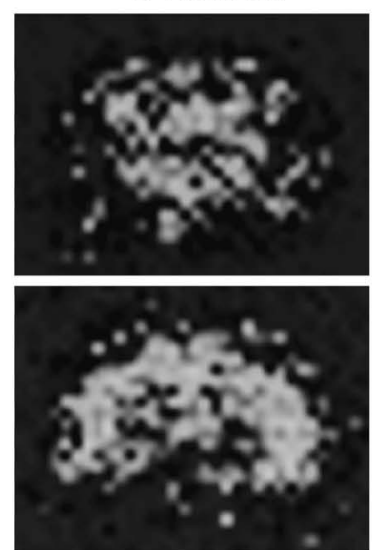

C ${ }^{14} \mathrm{C}-\mathrm{Neu} 5 \mathrm{Ac}$
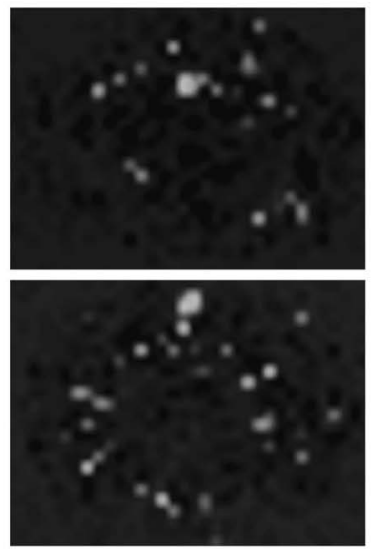

700

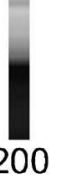

Fig. 5. Autoradiograms of ${ }^{14} \mathrm{C}-\mathrm{Neu} 5 \mathrm{Gc}$ and ${ }^{14} \mathrm{C}-\mathrm{Neu} 5 \mathrm{Ac}$ in the Brain after Tail Vein Injection ${ }^{47)}$

A, Schematic of brain regions. $\mathrm{H}$, hippocampus. B and C, Autoradiography of the rat brain was performed at $3 \mathrm{~h}$ after tail vein injection of ${ }^{14} \mathrm{C}-\mathrm{Neu} 5 \mathrm{Gc}(\mathrm{B})$ or ${ }^{14} \mathrm{C}-\mathrm{Neu} 5 \mathrm{Ac}(\mathrm{C})$.

謝辞＼cjkstart本研究を遂行するにあたり，ご指導，ご 支援を賜りました静岡県立大学薬学部 鈴木 隆教 授, 池田 潔教授, 大坪忠宗准教授, 金澤宽明教 授, 左一八教授, 高橋忠伸准教授, ともに研究に 取り組んできた学生の皆様に深謝申し上げます。ま た，今日まで温かいご助言とご鞭撻を賜りました恩 師, 静岡県立大学薬学部 奥 直人教授並びに武田 厚司教授, カリフォルニア大学バークレー校 Robert S. Zucker 教授に心より感謝申し上げます. 本研究は, 日本科学協会笹川科学研究助成, 内藤記 念特定研究助成金，天野工業技術研究所基金研究助 成金, 金原一郎記念医学医療研究助成金, 中部科学 技術センター学術奨励研究助成金, 双葉電子記念財 団自然科学研究助成金, 中部乳酸菌研究会研究助 成, グローバル COE プログラム, 糖鎖科学名古屋 拠点, 日本学術振興会科学研究費補助金 (若手研究 B, 21790085, 24790080）の助成を受けて実施した ものであり，ここに感謝申し上げます。

利益相反 開示すべき利益相反はない.

\section{REFERENCES}

1) Minami A., Otsubo T., Ieno D., Ikeda K., Kanazawa H., Shimizu K., Ohata K., Yokochi T., Horii Y., Fukumoto H., Taguchi R., Takahashi T., Oku N., Suzuki T., PLoS One, 9, e81941 (2014).

2) Otsubo T., Minami A., Fujii H., Taguchi R.,
Takahashi T., Suzuki T., Teraoka F., Ikeda K., Bioorg. Med. Chem. Lett., 23, 2245-2249 (2013).

3) Takahashi T., Otsubo T., Ikeda K., Minami A., Suzuki T., Biol. Pharm. Bull., 37, 16681673 (2014).

4) Takahashi T., Takano M., Agarikuchi T., Kurebayashi Y., Minami A., Otsubo T., Ikeda K., Suzuki T., J. Virol. Methods, 209, 136142 (2014).

5) Fukushima K., Takahashi T., Ueyama H., Takaguchi M., Ito S., Oishi K., Minami A., Ishitsubo E., Tokiwa H., Takimoto T., Suzuki T., FEBS Lett., 589, 1278-1282 (2015) .

6) Kurebayashi Y., Takahashi T., Otsubo T., Ikeda K., Takahashi S., Takano M., Agarikuchi T., Sato T., Matsuda Y., Minami A., Kanazawa H., Uchida Y., Saito T., Kawaoka Y., Yamada T., Kawamori F., Thomson R., von Itzstein M., Suzuki T., Sci. Rep., 4, 4877 (2014).

7) Takano M., Takahashi T., Agarikuchi T., Kurebayashi Y., Minami A., Otsubo T., Ikeda K., Kanazawa H., Suzuki T., Virology, 464465, 206-212 (2014).

8) Seki T., Rutishauser U., J. Neurosci., 18, 3757-3766 (1998).

9) Becker C. G., Artola A., Gerardy-Schahn R., Becker T., Welzl H., Schachner M., J. Neurosci. Res., 45, 143-152 (1996). 
10) Muller D., Wang C., Skibo G., Toni N., Cremer H., Calaora V., Rougon G., Kiss J. Z., Neuron, 17, 413-422 (1996).

11) Burgess A., Wainwright S. R., Shihabuddin L. S., Rutishauser U., Seki T., Aubert I., Dev. Neurobiol., 68, 1580-1590 (2008).

12) Shiozaki K., Koseki K., Yamaguchi K., Shiozaki M., Narimatsu H., Miyagi T., J. Biol. Chem., 284, 21157-21164 (2009).

13) Miyagi T., Yamaguchi K., Glycobiology, 22, 880-896 (2012).

14) Shiozaki K., Yamaguchi K., Takahashi K., Moriya S., Miyagi T., J. Biol. Chem., 286, 21052-21061 (2011).

15) Sumida M., Hane M., Yabe U., Shimoda Y., Pearce O. M., Kiso M., Miyagi T., Sawada M., Varki A., Kitajima K., Sato C., J. Biol. Chem., 290, 13202-13214 (2015).

16) Miyagi T., Tsuiki S., Eur. J. Biochem., 141, 75-81 (1984).

17) Bonten E. J., Campos Y., Zaitsev V., Nourse A., Waddell B., Lewis W., Taylor G., d'Azzo A., J. Biol. Chem., 284, 28430-28441 (2009) .

18) Ha K. T., Lee Y. C., Cho S. H., Kim J. K., Kim C. H., Mol. Cells, 17, 267-273 (2004).

19) Hasegawa T., Yamaguchi K., Wada T., Takeda A., Itoyama Y., Miyagi T., J. Biol. Chem., 275, 8007-8015 (2000).

20) Takahashi K., Mitoma J., Hosono M., Shiozaki K., Sato C., Yamaguchi K., Kitajima K., Higashi H., Nitta K., Shima H., Miyagi T., J. Biol. Chem., 287, 14816-14826 (2012).

21) Fujii I., Iwabuchi Y., Teshima T., Shiba T., Kikuchi M., Bioorg. Med. Chem., 1, 147-149 (1993).

22) Minami A., Shimizu H., Meguro Y., Shibata N., Kanazawa H., Ikeda K., Suzuki T., Neuroimage, 58, 34-40 (2011).

23) Saito M., Hagita H., Iwabuchi Y., Fujii I., Ikeda K., Ito M., Histochem. Cell Biol., 117, 453-458 (2002).

24) Miyagi T., Takahashi K., Moriya S., Hata K., Yamamoto K., Wada T., Yamaguchi K., Shiozaki K., Adv. Exp. Med. Biol., 749, 257-267 (2012).

25) Nomura H., Tamada Y., Miyagi T., Suzuki A., Taira M., Suzuki N., Susumu N., Irimura T., Aoki D., Oncol. Res., 16, 289-297 (2006).

26) Zhao C., Teng E. M., Summers R. G. Jr.,
Ming G. L., Gage F. H., J. Neurosci. 26, 3-11 (2006).

27) Seki T., J. Neurosci. Res., 70, 327-334 (2002).

28) Seki T., Arai Y., J. Neurosci., 13, 2351-2358 (1993).

29) Da Silva J. S., Hasegawa T., Miyagi T., Dotti C. G., Abad-Rodriguez J., Nat. Neurosci., 8, 606-615 (2005).

30) Rodriguez J. A., Piddini E., Hasegawa T., Miyagi T., Dotti C. G., J. Neurosci., 21, 8387-8395 (2001).

31) Seki T., Arai Y., J. Comp. Neurol., 410, 115125 (1999).

32) Isaeva E., Lushnikova I., Savrasova A., Skibo G., Holmes, G. L., Isaev D., Eur. J. Neurosci., 32, 1889-1896 (2010).

33) Isaeva E., Lushnikova I., Savrasova A., Skibo G., Holmes G. L., Isaev D., Pharmacol. Rep., 63, 840-844 (2011).

34) Isaev D., Isaeva E., Shatskih T., Zhao Q., Smits N. C., Shworak N. W., Khazipov R., Holmes G. L., J. Neurosci., 27, 11587-11594 (2007).

35) Hammond M. S., Sims C., Parameshwaran K., Suppiramaniam V., Schachner M., Dityatev A., J. Biol. Chem., 281, 34859-34869 (2006).

36) Hoffman K. B., Kessler M., Lynch G., Brain Res., 753, 309-314 (1997).

37) Isomura R., Kitajima K., Sato C., J. Biol. Chem., 286, 21535-21545 (2011).

38) Kanato Y., Kitajima K., Sato C., Glycobiology, 18, 1044-1053 (2008).

39) Minami A., Suzuki T., Trends Glycosci. Glycotech., 24, 112-121 (2012).

40) Furuse H., Waki H., Kaneko K., Fujii S., Miura M., Sasaki H., Ito K. I., Kato H., Ando S., Exp. Brain. Res., 123, 307-314 (1998).

41) Jung W. R., Kim H. G., Kim K. L., Neurosci. Lett., 439, 220-225 (2008).

42) Ramirez O. A., Gomez R. A., Carrer H. F., Brain Res., 506, 291-293 (1990).

43) Wieraszko A., Seifert W., Brain Res., 345, 159-164 (1985).

44) Dityatev A., Dityateva G., Sytnyk V., Delling M., Toni N., Nikonenko I., Muller D., Schachner M., J. Neurosci., 24, 9372-9382 (2004). 
45) Kochlamazashvili G., Senkov O., Grebenyuk S., Robinson C., Xiao M. F., Stummeyer K., Gerardy-Schahn R., Engel A. K., Feig L., Semyanov A., Suppiramaniam V., Schachner M., Dityatev A., J. Neurosci., 30, 4171-4183 (2010) .

46) Lopez-Fernandez M. A., Montaron M. F., Varea E., Rougon G., Venero C., Abrous D. N., Sandi C., J. Neurosci., 27, 4552-4561 (2007).

47) Taguchi R., Minami A., Matsuda Y., Takahashi T., Otsubo T., Ikeda K., Suzuki T., PLoS One, 10, e0131061 (2015).

48) Minami A., Ishibashi S., Ikeda K., Ishitsubo E., Hori T., Tokiwa H., Taguchi R., Ieno D., Otsubo T., Matsuda Y., Sai S., Inada M., Suzuki T., FEBS Open Bio, 3, 231-236 (2013).
49) Corfield A. P., Veh R. W., Wember M., Michalski J. C. Schauer R., Biochem. J., 197, 293-299 (1981).

50) Davies L. R., Pearce O. M., Tessier M. B., Assar S., Smutova V., Pajunen M., Sumida M., Sato C., Kitajima K., Finne J., Gagneux P., Pshezhetsky A., Woods R., Varki A., J. Biol. Chem., 287, 28917-28931 (2012).

51) Boyzo A., Ayala J., Gutierrez R., Hernandez R. J., Brain Res., 964, 211-217 (2003) .

52) Lukong K. E., Seyrantepe V., Landry K., Trudel S., Ahmad A., Gahl W. A., Lefrancois S., Morales C. R., Pshezhetsky A. V., J. Biol. Chem., 276, 46172-46181 (2001).

53) Yamaguchi K., Hata K., Wada T., Moriya S., Miyagi T., Biochem. Biophys. Res. Commun., 346, 484-490 (2006). 